\title{
U⿱宀⿻三丨口
}

\section{Community-Based Justice in Northern Ireland and South Africa}

Monaghan, R. (2008). Community-Based Justice in Northern Ireland and South Africa. International Criminal Justice Review, 18(1), 83-105. https://doi.org/10.1177/1057567708316639

Link to publication record in Ulster University Research Portal

\section{Published in:}

International Criminal Justice Review

Publication Status:

Published (in print/issue): 01/03/2008

DOI:

$10.1177 / 1057567708316639$

\section{Document Version}

Publisher's PDF, also known as Version of record

\section{General rights}

Copyright for the publications made accessible via Ulster University's Research Portal is retained by the author(s) and / or other copyright owners and it is a condition of accessing these publications that users recognise and abide by the legal requirements associated with these rights.

\section{Take down policy}

The Research Portal is Ulster University's institutional repository that provides access to Ulster's research outputs. Every effort has been made to ensure that content in the Research Portal does not infringe any person's rights, or applicable UK laws. If you discover content in the Research Portal that you believe breaches copyright or violates any law, please contact pure-support@ulster.ac.uk. 


\title{
International Criminal Justice Review
}

http://icj.sagepub.com

\section{Community-Based Justice in Northern Ireland and South Africa \\ Rachel Monaghan \\ International Criminal Justice Review 2008; 18; 83 \\ DOI: $10.1177 / 1057567708316639$ \\ The online version of this article can be found at: http://icj.sagepub.com/cgi/content/abstract/18/1/83}

\author{
Published by: \\ (3)SAGE \\ http://www.sagepublications.com
}

On behalf of:

Georgia State University, College of Health and Human Sciences

Additional services and information for International Criminal Justice Review can be found at:

Email Alerts: http://icj.sagepub.com/cgi/alerts

Subscriptions: http://icj.sagepub.com/subscriptions

Reprints: http://www.sagepub.com/journalsReprints.nav

Permissions: http://www.sagepub.com/journalsPermissions.nav

Citations http://icj.sagepub.com/cgi/content/refs/18/1/83 


\title{
Community-Based Justice in Northern Ireland and South Africa
}

Rachel Monaghan

University of Ulster

\begin{abstract}
South Africa and Northern Ireland have experienced bitter ethnonational conflicts in which the transition to a peaceful political settlement has been characterized by crime and violence. In the case of Northern Ireland, this transition is still ongoing. This article examines the alternative policing and informal justice mechanisms, which have developed in the townships of South Africa and within the working-class districts of Northern Ireland. These mechanisms offer the inhabitants of such areas instant redress and retributive justice. This article is also concerned with the community-based restorative justice projects, which have been established in certain areas within both countries and examines whether such projects have an impact on vigilante attacks in South Africa and paramilitary "punishments" in Northern Ireland.
\end{abstract}

Keywords: restorative justice; retributive justice; postconflict societies

Thepe

The following article is concerned with community-based restorative justice mechanisms operating in two countries that have a history of retributive justice linked to the political conflicts, which have dominated their pasts. The current crime situation is outlined in the countries under discussion as is the community-based justice mechanisms in operation. Moreover, the potential nexus between restorative and retributive justice is explored and to this end, the following research question is addressed: Does the operation of community-based restorative justice schemes have any impact on community-based retributive justice mechanisms?

The two countries under examination are South Africa and Northern Ireland. Both countries may be considered "post-conflict" societies and merit academic enquiry, which could promote policy learning both within and between them and, more generally, other countries emerging from conflict. South Africa and, more tentatively, Northern Ireland are emerging from bitter ethno-national conflicts in which violence and crime characterized the transition to peaceful political settlements. The collapse of apartheid in 1989, lifting the 30-year ban on the African National Congress (ANC) and the subsequent release of Nelson Mandela, created a climate for political negotiation and change in South Africa. This paved the way for an interim constitution, the first multiracial democratic elections in 1994, and led to the Government of National Unity. The ANC's success in both the June 1999 and April 2004 elections has given the party an overwhelming mandate to accelerate Thabo Mbeki's program of "transformation" aimed at tackling

\footnotetext{
Author's Note: The author acknowledges the support of ESRC funding (RES-000-22-1013) to carry out this work, the contribution of Dawn Purvis with aspects of the fieldwork, the assistance of Pat McKee and Pat McGregor with the time-series analysis, and the comments and suggestions of the anonymous reviewers. Correspondence concerning this article should be addressed to Dr. Rachel Monaghan, School of Policy Studies, University of Ulster, Newtownabbey, BT37 0QB, Northern Ireland; e-mail: r.monaghan@ulster.ac.uk.
} 
Figure 1

\section{Recorded Violent Crime and Property Crime in South Africa}

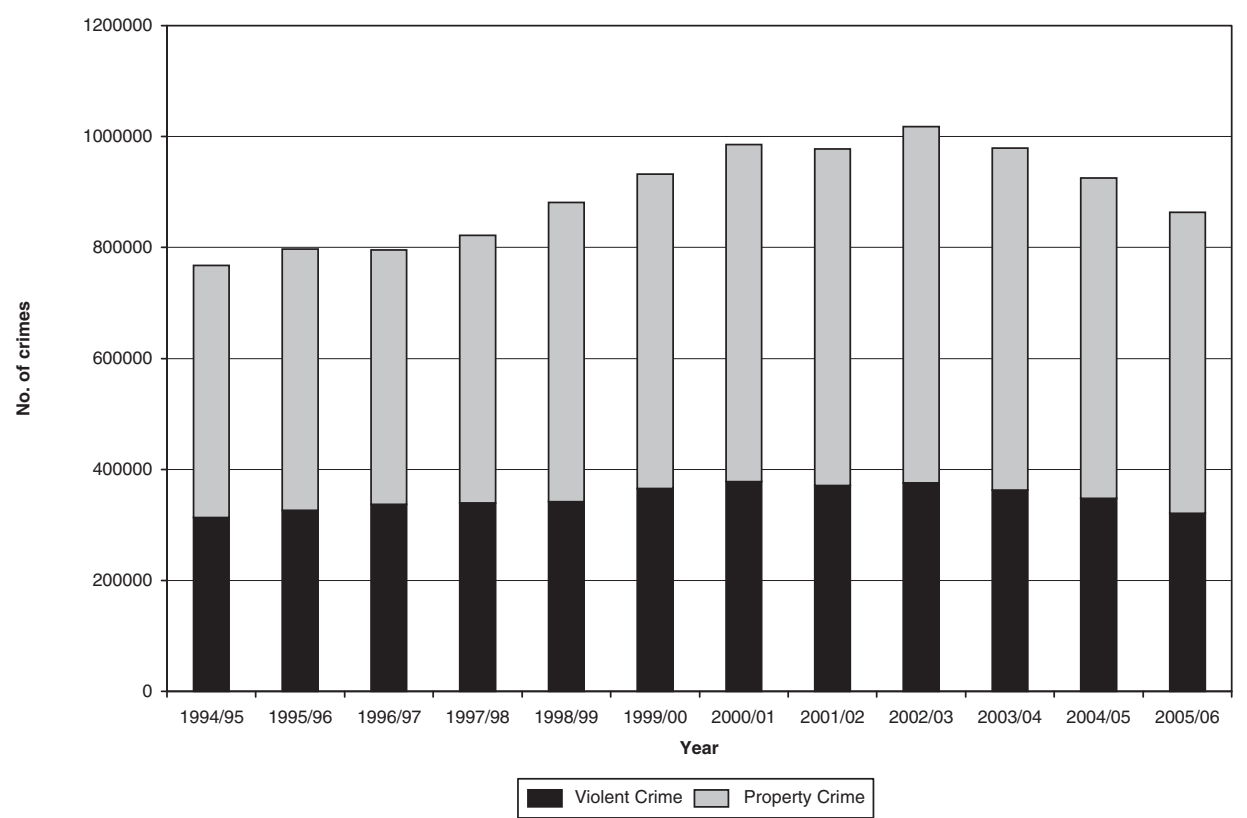

Source: South African Police Service.

the significant socioeconomic problems facing South Africa: unemployment, AIDS, crime, and education. The legacy of political resistance, often violent, deployed to make the townships ungovernable during apartheid, has created a culture tolerant of citizens taking the law into their own hands. Although the number of political killings dropped sharply from about 2,500 in 1994 to 52 in 2002 (South African Institute of Race Relations, 2001; The Economist, 2003), Mbeki (1999, p. 1), in his inauguration speech, regretted that some South Africans were "forced to beg, rob and murder to ensure that they and their own do not perish from hunger." According to Altbeker (2005), there are two forms of criminality that dominate the public psyche, namely, "violent crime" and "property crime." The former includes murder, attempted murder, serious assault, and rape, whereas the latter encompasses aggravated robbery, common robbery, car/motorbike theft, and burglary at residential premises. As seen in Figure 1, recorded levels of violent crime rose by some $20 \%$ between $1994 / 1995$ and 2002/2003, and since then they have declined by $15 \%$.

A similar trend can also be observed with regard to recorded levels of property crime, which rose by $41 \%$ between $1994 / 1995$ and $2002 / 2003$ before declining by nearly $15 \%$. Recent research from a national victim survey suggests that less than half of all crime is reported to the police (Burton et al., 2004) and that more than one in five South Africans had been a victim of crime in the 12 months preceding the survey (Mistry, 2004).

Furthermore, research and public opinion alike regard the formal criminal justice system as weak. Criminals are unlikely to be caught and still less likely to be convicted. The South African Law Commission (2003, p. 26; hereafter referred to as the Commission) concluded that crime pays and that "South African criminals, even violent criminals, tend to get away 
with their crimes," with only 6 out of every 100 violent crimes recorded by the South African Police Service (SAPS) resulting in a conviction. Their research tracked more than 15,000 cases initiated in 1987 and 1998 for a period of 2 years and suggest that "three-quarters of cases involving murder, rape and robbery with aggravating circumstances have not even made it to court after two years" (p. 26). Furthermore, they found conviction rates for rape of a girl under 18 were less than one in ten $(9 \%)$, reported murder cases $11 \%$, adult rape $5 \%$, and aggravated robbery 3\%. Despite the recent fall in recorded levels of crime, the introduction of a new elite police force (the Scorpions) for investigation, prosecution and intelligence, a range of new laws mandating minimum sentences, tightening bail, and an increase in resources for the police, the fear of crime among South Africans has increased:

The results of South Africa's second national victim survey [2003], as well as the police statistics, show that crime rates have either decreased or leveled off over the last five years. However, according to the victim survey the public's fear of crime has simultaneously increased. (Mistry, 2004, pp. 23-24)

Northern Ireland's transition to "peace" has been more recent and capricious. The signing of the Belfast Agreement in April 1998, and its subsequent endorsement in referenda by its electorate $(71.2 \%)$ and voters in the Irish Republic $(94 \%)$, heralded a political solution to the seemingly intractable problems, which bedeviled the province for 30 years. The British and Irish Governments formally resolved their historical differences through the general and mutual acceptance of the principle of consent-Northern Ireland is part of the United Kingdom, and will remain so, as long as a majority wishes. The Irish constitution (Articles 2 and 3) was amended to reflect this understanding, and power was devolved (December 1999) to a locally elected Northern Ireland Assembly with a wide range of executive and legislative powers. The Agreement also contained measures designed to create a "normal and peaceful society in Northern Ireland." The most significant included the early release of political prisoners, parallel reviews of the policing and criminal justice systems, new independent Human Rights and Equality Commissions, and a commitment from participants to total disarmament of all paramilitary organizations by working with the Independent International Commission on Decommissioning (IICD). Failure to resolve the arms issue (prosaically described as "no guns, no government") led to the temporary suspension of the Northern Ireland Assembly and Executive in February 2000 and August 2001, a political impasse, and the reimposition of Direct Rule from Westminster. ${ }^{1}$ By September 2005, the PIRA had satisfied the IICD's Chair, General de Chastelain, that it had "put all of its arms beyond use" (IICD, 2005, p. 2).

Deaths resulting from the security situation have been declining since 2001, and no security force personnel has been murdered since 1998. This, however, conceals an increasing level of "violent crime," defined as offences against the person, sexual offences, and robberies. In $1999 / 2000$, the police recorded 24,163 violent crimes, and by 2006/2007 this had increased by $46 \%$ to 35,223 (Report of the Chief Constable, 2000, 2007). A Home Office report (Barclay \& Tavares, 2000) on international crime statistics showed Northern Ireland's percentage increase in recorded crime (28\%) as second only to South Africa where it rose by $37 \%$ in 1998 . In comparison, a number of countries recorded decreases in the number of crimes recorded by the police, for example, the United States $(-5 \%)$, the Republic of Ireland (-6\%), and Denmark $(-6 \%)$. 
Northern Ireland $(+21 \%)$ also experienced the largest rise of the 29 countries examined in the report in the area of recorded violent crime (Barclay \& Tavares, 2000). Statistics on violent crime include "punishment" beatings, and shootings perpetrated by paramilitary groups in their role as community "protectors" upholding the law in areas they control. Up to the end of 2006 police statistics show there have been 3,126 shootings and 2,377 beatings since the figures were first recorded. ${ }^{2}$ These statistics, however, are thought to grossly underestimate the true extent of the problem. Those subjected to beatings and shootings are fearful of involving the security forces in case of paramilitary reprisal and hence there is large-scale underreporting. Paramilitary groups, particularly republicans, have historically rationalized their activities as policing their own communities in the absence of a "legitimate police force." As Morrissey and Pease (1982, p. 163) explain,

The population of West Belfast had no confidence in the Royal Ulster Constabulary which was perceived as a sectarian force with no interest in supporting the population of that area. In these circumstances, it was said a demand had grown for a better system of justice and the [P.]I.R.A. was the only organisation with the resources to develop an effective one.

Furthermore, communities are discouraged from going to the police as the experience is that charges will be dropped against perpetrators in return for low-level intelligence information useful to the police (Knox \& Monaghan, 2002). Loyalist paramilitaries, on the other hand, tend to engage in "punishment" attacks as much to maintain discipline among their own members as to "police" their areas (Silke, 1999).

This brief overview of the two countries suggests several things. First, communities, which have been brutalized during conflicts over a long period, become desensitized to violent crime. In the case of Northern Ireland, this has been variously described by a former Secretary of State as "the peace we have now is imperfect, but better than none" or perhaps, more tersely, as having "an acceptable level of violence" (Mowlam, 1999). Second, within conflict settings, crime can be differentiated into "political" and "normal" crime. The former could include informing and collaborating with the "enemy" even though such activities would not necessarily be deemed as criminal by the State. In contrast, "normal" crime would include break-ins, muggings, rape, car theft, and drug-dealing, criminal offences necessitating action by the formal justice system. When the legitimacy of the State and effectiveness and impartiality of its organs (the security forces and legal system) are integral to the nature of the conflict, however, this forecloses recourse to the usual channels by which communities seek to tackle "normal" crime. Third, and as a direct consequence, communities develop their own responses to crime, informal justice mechanisms, which will be heavily influenced by the violent environment within which they live. In Northern Ireland, these are located within working-class communities, whereas in South Africa they are confined to the Black townships. These mechanisms can be divided into two types, punitive sanctions meted out by agents of informal justice, paramilitaries in the case of Northern Ireland and vigilantes in the South African context, and second, nonviolent restorative justice schemes. The concern of this article is with the latter. In Northern Ireland, restorative justice is a relatively recent approach taken by working-class communities, whereas in South Africa's townships it has a long history. This article will examine the operation of such schemes in the two countries under discussion and assess whether their operation affects the violent system of punitive sanction that already exists. 


\section{Community-Based Retributive Justice in Northern Ireland and South Africa}

Since the beginning of "The Troubles" in 1968, alternative forms of justice have emerged in the working-class areas of Northern Ireland, although academics did not study the phenomenon until the early 1980s (Hillyard, 1985; Morrissey \& Pease, 1982; Munck, 1984). Such justice is undertaken by paramilitaries and involves a range of punitive measures against individuals "who violate some community norm, as defined by the paramilitary grouping" (Kennedy, 1995, p. 69). As noted, activities liable for "punishment" can be divided into two main categories, "political" and "normal" crime. "Normal" crime also encompasses "antisocial behavior." Activities considered "antisocial" by paramilitaries are diverse in nature and would include youths gathering at street corners, the playing of music too loudly, the verbal abuse of senior citizens, and the dumping of rubbish. A tariff system developed in both republican and loyalist areas. As Conway (1997) notes, this tariff system reflected the formal (state) criminal justice system, albeit in a more extreme form. Furthermore, force is perceived by many as the predominant policing method of the paramilitaries (Brewer, Lockhart, \& Rogers, 1998). Thus informal justice involves a graduated scale of sanctions escalating from threats or warnings, through curfew, public humiliation, exile and "punishment" beating, to kneecapping or, in exceptional circumstances, "execution." Beatings are carried out using instruments such as baseball bats, golf clubs, pickaxe handles, iron bars, hammers, sledgehammers, and hurley sticks spiked with nails to inflict puncture wounds on victims. Assaults are aimed directly at bones to cause multiple fractures. For example, Ian Price, a 13-year-old, was singled out from a group of friends by masked men, pushed to the ground and beaten with baseball bats studded with nails. He suffered a shattered elbow, broken fingers, deep puncture wounds to his legs, cuts and multiple bruising (McGuigan, 1999). Furthermore, those beaten may be tied upright to fence railings, thereby leaving them unable to shield themselves. Individuals have also had breezeblocks dropped onto their limbs. Shootings can also vary; a gunshot wound to the fleshy part of the thigh heals relatively quickly compared to injuries to the bone, which can lead to permanent maiming. The seriousness of the crime will affect the number of times an individual is shot, the caliber of weapon used, and the proximity of the wound to the joints (Bell, 1996). For example, Jim Lismore, a father of two and self-confessed ex-drugs dealer was shot through both hands; feet and elbows (also known as a "six-pack") allegedly for his past activities (Doyle, 2001). The "punishment" ordered would in theory be influenced by mitigating factors, for instance age, gender, past criminal record, and family background. In practice, however, the level of "punishment" can be arbitrarily brutal or lenient, depending on whether the offender had paramilitary connections or not.

An increasing trend is exiling - a demand to leave a local area, city, Northern Ireland or Ireland. The exiling or expulsion of alleged criminals or "antisocial" elements can vary in time from 6 months to a year and beyond. In some cases, people are ordered out indefinitely. Expulsion orders are usually accompanied by both a leeway period of between 24 and 48 hours and an "or else." Men, women, young people under 16 years of age and, in some instances, whole families have been exiled. Patricia McDaid and her family were given 72 hours to leave the Craigavon housing estate in which they lived and were told not to stay in the area (Templeton, 2000). Although figures are difficult to substantiate, nearly 1,600 have been exiled in the period 1995 to 2000, according to a report by the Northern Ireland Affairs Committee (2001) entitled "Relocation Following Paramilitary Intimidation." 
The initial rationale for this informal justice system within Northern Ireland differs between the two main communities. On the republican side, the unacceptability and lack of legitimacy of the police in Northern Ireland during the course of the "Troubles" led to its initial establishment (Brewer et al., 1998; McEvoy \& Mika, 2002), whereas on the loyalist side, early informal justice mechanisms were designed to assist the police (Monaghan, 2002). As the "Troubles" continued a policing vacuum emerged in both communities; subsequently, paramilitaries were called on by local communities "to do something" about crime and antisocial behavior in their areas. Research by Knox and Monaghan (2002) found three main reasons for the continuance of community-based retributive justice. These included (a) the unacceptability of the police in republican communities/the inability of the police in loyalist areas to deal with crime, (b) the rise in petty crime and antisocial behavior in such communities, and (c) the perceived leniency of the formal criminal justice system in dealing with offenders. As McEvoy and Mika (2002) note "punishment violence is often quite popular in the communities in which it occurs as a swift and visible dispensation of "justice"” (p. 536).

Likewise in South Africa, alternative forms of justice can be found in the Black townships. During the apartheid years, township inhabitants developed informal criminal justice mechanisms for dealing with crime in their community. These mechanisms were developed, in part, from traditional rural practices such as the lekgotla, a court comprising elders from the community who listened to disputes and problems and passed judgment. The lekgotla emphasized a conservative moral code, including respect for elders, the importance of kin and patriarchal authority, while also advocating the restoration of harmony and the reintegration of offenders into the community. Sentences handed down to those found guilty, included fines, corporal punishment, and community service. Neighborhood patrols and street committees were also established in an attempt to deal with "normal" crime, for instance robbery, theft, and rape. With the emergence of the politicized youth or "comrades," people's courts were established within the townships, and residents were encouraged to take their problems to the "comrades." These courts were seen as part of the political struggle against apartheid because they represented an alternative to the state structure and dealt with both "normal" and "political" crime. Gradually these courts, which numbered some 400 by 1987 , began to acquire the reputation of "kangaroo courts" (Brogden \& Shearing, 1993; Minnaar, 1995). Such courts were characterized by their predetermined assumption of guilt of the accused, instant redress, and engagement in human rights abuses. The people's courts of the "comrades" in some cases meted out beatings and whippings with a sjambok, with sentences of up to 300 lashes, and on occasions a death sentence was passed. By the mid-1980s, those individuals accused of "political" crimes such as collaborating, informing, or being a "sell-out" (working as a councilor or a police officer) were "necklaced" for their alleged crimes. The necklace method involves the placing of a petrol-filled tire around the accused's neck that is then set alight. Estimates suggest that between 1985 and 1990 some 350 to 400 people were killed by this method of execution with another 500 necklaced between 1990 and 1994 (Minnaar, 1995).

The advent of a negotiated settlement to the political conflict and the holding of multiracial elections have not resulted in the disappearance of retributive informal justice in the "new" South Africa. The "comrades" are no longer involved in such justice, rather new groups have emerged. These include the Peninsula Anti-Crime Agency (PEACA) ${ }^{3}$ in the Western Cape, Mapogo a Mathamaga ${ }^{4}$ in the Northern Province, and the willingness of taxi associations in some townships to become involved in crime solving for a fee. All these 
groups stand accused of using corporal punishment and violence in responding to crime. Indeed Mapogo's leader, John Magolego, asserts that public flogging "is the African way of stopping crime. The criminal must lie on the ground, and we must work on his buttocks and put him right" (cited in Soggot \& Ngobeni, 1999). Alleged suspects are usually beaten until they confess or provide information as to the whereabouts of stolen goods. Mapogo has also been accused of throwing suspects into crocodile-infested waters, whereas taxi drivers in Guguletu are implicated in dragging alleged criminals behind vehicles.

Furthermore, in some cases, spontaneous mobs form to mete out justice to alleged criminals. In some instances, those present convene kangaroo courts, but this is not always the case. The justice meted out is often of an extremely brutal nature and deaths are common. Recent examples in the townships include the stoning to death of an alleged arsonist near Pretoria ("The Pretoria News," 2006) and the beating to death of a man accused of trying to hijack a car in Johannesburg (South African Press Association, 2006). In some cases, members of a suspected criminal's family or the family home are targeted. Their houses are either destroyed or burnt and often the families subsequently leave the area as a result of intimidation. In June 2006, three suspected robbers, a mother, her son, and another man were rescued by the police after a mob of nearly 1,000 North West Province residents destroyed their home and set their vehicles alight (Hosken, 2006).

Initial explanations for the existence of informal justice mechanisms in South Africa are rooted in historic antecedents, based on indigenous African laws, customs, and institutions, as a response to a policing vacuum and rising crime in the townships and as opposition to apartheid (Brogden \& Shearing, 1993; Nina, 1995; Seekings, 1992). Despite the ending of apartheid, the negotiation of a political settlement, and the introduction of the "new" South Africa, retributive informal justice has not disappeared. As Knox and Monaghan (2002) note "high crime rates, perceived police ineffectiveness and alleged corruption within the criminal justice system have contributed to the continued existence of retributive informal justice" (p. 82). It is within this context that alternative ways of tackling communal violence in Northern Ireland and South Africa are considered.

\section{Restorative Justice}

Restorative justice can be understood in a number of ways. Braithwaite and Strang (2001) contend that within the literature restorative justice is conceived in two distinct conceptions, namely, as a process and as a set of values. For some such as Marshall (2003),

Restorative justice is a process whereby parties with a stake in a specific offence resolve collectively how to deal with the aftermath of the offence and its implications for the future. (p. 28)

Whereas for others, like Braithwaite (2003), restorative justice is understood as a set of distinctive values, including constraining values (e.g., nondomination, empowerment, and accountability), maximizing values (e.g., restoration of property loss and dignity, compassion, social support, and prevention of further injustice), and emergent values (e.g., remorse over injustice, forgiveness, and mercy). Restorative justice, therefore, "moves from punishment to reconciliation, from vengeance against offenders to healing victims, from alienation and harshness to community and wholeness, from negativity and destructiveness to healing, forgiveness and mercy" (Consedine, 1999, p. 10). 
Table 1

Key Attributes of the Retributive and Restorative Justice Models

\begin{tabular}{ll}
\hline Retributive & \multicolumn{1}{c}{ Restorative } \\
\hline Crime violates laws set by government & Crime violates relationships between people \\
Focus on placing guilt & Focus on needs and responsibilities \\
State is central to the process & Victim and offender are central to the process \\
Rules are key & Assumption of responsibility is key \\
Victim plays minimal role & Victim's participation vital \\
Offender takes mostly passive role & Offender required to be active in the process \\
Offender marginalized from the community & Offender marginalization decreased \\
Directed and led by professionals & Community and voluntary involvement \\
Focus on the past & Focus on the future \\
Low percentage of restitution & High percentage of restitution \\
\hline
\end{tabular}

Source: Hall (2000, p. 4).

Restorative justice can also be understood as a distinctive paradigm of justice. Much of the justice that is experienced in many liberal democracies such as the United Kingdom and South Africa falls into what is defined as the retributive paradigm. In this paradigm, crime is viewed as a violation of law and an offence against the state. In contrast, Zehr (2003) suggests an alternative paradigm, where crime is a violation against a person. Therefore, the response to such a violation requires not retribution but restoration. This restorative justice paradigm "would encourage responsibility for past behavior, its focus would be on the future, on problem-solving, on the obligations created by the offence" (p. 80). The distinction between the two approaches can be clearly seen in Table 1.

In addition, restorative justice can be considered as a normative social theory encompassing an alternative vision of a just and nonviolent society. Gil (2006) contends that if we wish to "fully realize the philosophical principles of restorative justice, its practitioners and students would have to move beyond rehabilitation and reintegration of offenders and victims to counter-violent tendencies and behaviour" (p. 499). Thus from this perspective, restorative justice is a transformative process and is concerned with structurally violent and unjust societies (Sullivan \& Tifft, 2000).

Closely linked to this perspective is the view that restorative justice can be understood as a lifestyle and that we can apply its principles and values in our everyday interaction with others. Boehrer (2006) believes that restorative justice involves a needs-based approach involving alternatives to the state definitions of help, a personal responsibility for other people, an experience of vulnerability (e.g., in terms of finances, health, and emotions) and a sensitivity to the vulnerabilities of others. Boehrer contends that "the greatest challenge of restorative justice is to confront the social structural violence that pervades the fabric of our culture" (p. 554).

Thus the concept of "restorative justice" is not a unitary one nor does it propose a singular academic theory of crime or justice. Consequently, it is a difficult concept to define. Restorative justice has become "a convenient shorthand expression that is commonly applied to a variety of practices which seek to respond to crime in a more constructive way than is conventionally achieved through the use of punishment" (Dignan \& Lowey, 2000, 
p. 3). Although there is no universal definition or theory of restorative justice, there is agreement within the literature that restorative justice represents a unique approach in terms of responding to offending behavior and is distinctly different from traditional retribution.

For the purpose of this article, restorative justice will be understood to involve a tripartite relationship between victims, offender, and the community. As Gilbert and Settles (2007) note,

Collaborative problem solving through shared, nonadversarial dialogue accomplishes many things. It humanizes both victim and offender by allowing them to express their feelings to one another, recognizes the harms experienced, allows the offender to explain his or her actions, clarifies and reinforces community values, strengthens informal social controls, and empowers residents to work together to improve their community. (p. 7)

Thus any scheme or project based on the principles of restorative justice must seek to (a) meet the needs of victims, (b) make the offender accountable for their actions and offer a pathway back into the community, and (c) give communities a sense of ownership and responsibility over dealing with crime in their areas (McEvoy, 1999).

\section{Community-Based Restorative Justice in Northern Ireland}

Alternatives to the formal justice system (both violent and nonviolent), according to Bell (1996), existed in Ireland as far back as the 18th century when revolutionary agrarian organizations challenged British rule and justice. These challenges included alternative arbitration tribunals and more violent acts of injuring caretaker farmers who replaced those evicted from their holdings. The contemporary debate, however, is directly linked to the outbreak of "The Troubles." At the outset, this involved tactics such as tarring and feathering young women who consorted with British soldiers, public humiliation of offenders by ordering them to wear placards (e.g., "I am a housebreaker"), and "breezeblocking"-inflicting punishment by dropping blocks on to the limbs of the accused. As the conflict developed, so too did the informal justice system. Paramilitary groups, particularly in republican areas of Northern Ireland, became less tolerant of those whom they perceived as undermining "the republican struggle" by their "antisocial behavior" and turned their weaponry on them. Loyalist groups engaged in similar tactics but for different reasons. Beatings and shootings were used to maintain internal discipline within and between the more heterogeneous loyalist factional groups.

A number of things changed, however, which resulted in a radical rethink on the use of punitive sanctions. First, the political environment altered radically. The multiparty talks, chaired by Senator George Mitchell, committed the political parties, including those with paramilitary links (the Ulster Democratic Party, the Progressive Unionist Party, and Sinn Féin), to "democratic and exclusively peaceful means of resolving political issues." All participating parties signed up to six fundamental principles of democracy and nonviolence, one of which urged that "punishment" killings and beatings stop and parties take effective steps to prevent such actions. Second, external pressure was exerted by the Dublin and American administrations, both of which had political clout with the British Government, on political parties linked to paramilitaries to end their involvement or endorsement of this kind of violence. Interestingly, paramilitary attacks ceased during the Clinton visits to Northern Ireland in 1995 and 1998. The case was made that the Belfast Agreement and 
pledged reforms of the Royal Ulster Constabulary (RUC) $)^{5}$ and criminal justice system would obviate the need for informal justice administered through paramilitaries. Third, working-class communities felt increasingly repressed by what they perceived as violent control exercised by paramilitaries, particularly in loyalist areas where in ceasefire circumstances, they have diversified further into drugs, racketeering, and extortion. There has therefore been a muted community reaction, through fear of reprisal, to the "brutalisation of their young men." In transitional circumstances where a new policing service and criminal justice system were promised, recorded crime was increasing, and the raison d'être for paramilitary groups during a time of "peace" was questioned, an alternative to punitive sanctions emerged in the form of restorative justice program in both loyalist and republican areas. As McGloin (2006) notes these programs are often "private and outside of the official domain of the criminal justice system" (p. 91). Two of the most prominent schemes are considered here-the Greater Shankill Alternatives program on the loyalist side and the republican Community Restorative Justice (CRJ) Scheme.

\section{The Greater Shankill Alternatives Program}

The genesis of the program in the loyalist community is rooted in a research project undertaken during 1996 by an ex-political prisoner (Winston, 1997) in the Greater Shankill District of Belfast. The research was initiated in both communities by the Northern Ireland Association for the Care and Resettlement of Offenders ${ }^{6}$ (NIACRO) and funded by a private American donor (widely reported to be Charles "Chuck" Feeney). It was designed to explore, with a range of community activists (including loyalist paramilitaries), the potential for an alternative strategy to "punishment" beatings, and shootings.

This work provided the context for the Greater Shankill Alternatives program, which began in September 1998 with the endorsement of the paramilitary groups, the Ulster Volunteer Force (UVF), and the Red Hand Commando (RHC), but not the Ulster Defence Association (UDA). ${ }^{7}$ This, in itself, is significant and demonstrates the factionalism within loyalism. The rationale for the approach adopted is based on the perceived failings of the formal criminal justice system where crime is treated as a violation of the law, which elicits retribution-hence equating punishment with justice. This scheme treats crime as a breakdown in human relationships, and the focus is on healing and repairing the harm caused by crime. "Alternatives" receives referrals from Social Services, the Probation Board, victims, and the families of offenders and paramilitaries. Although as Tom Winston, the Project Manger for Alternatives, acknowledges, few referrals "are now from paramilitary organisations, maybe about 5-10 per cent . . . where in the past it would've been 80-90 per cent and that's simply because people are aware of us now and they're coming directly to us for help" (Interview, December 2005). Additional projects have been established in north Belfast (Ballysillan), in east Belfast (Woodstock area), and in Bangor on the Kilcooley estate.

An "investigation" is carried out to establish the facts and veracity of the victim's claim. When complete, the needs of the victim are determined and a contract is drawn up with the offender to fulfil those needs. To assist in this process, a trained community mediator facilitates a face-to-face meeting between victim and offender. The outcome is an agreed determination, endorsed by a community panel of local volunteers, between the victim and 
offender as to the appropriate form of "justice." This may, for example, be restitution for damage caused, an apology and/or an agreed period of volunteer work in the community linked in some way to the original "antisocial behavior." Victims may decide not to meet offenders, but their views are incorporated into the process in a way that is not provided for within the formal criminal justice system.

The project claims good relations with the major statutory agencies for the work they do, although the position of the police is rather ambiguous. There appears to be support from local police, where "Alternatives" is seen as a useful collaborative model, but there is suspicion among the higher ranks. In part, this has to do with the police's long-standing monopoly on tackling crime, compounded by their role in policing terrorism within the very areas where they are now expected to work in partnership with communities. Police involved in the Shankill scheme point out that if the police endorse the "Alternatives" program it might create political pressure for them to endorse restorative justice programs in republican areas where the police, by design, are not involved (Knox \& Monaghan, 2002). The republican scheme is now considered.

\section{The CRJ Scheme}

The republican CRJ scheme had similar origins. With private donor backing, NIACRO approached Sinn Féin to explore ways in which nonviolent alternatives might be found to tackle community crime. This resulted in a series of seminars, organized by NIACRO, on crime and justice issues that looked at topics such as policing in an international context, the nature of offending, and juvenile delinquency. This was followed by a weekend residential program, out of which came a publication titled, Designing a System of Restorative Community Justice in Northern Ireland (Auld et al., 1997), referred to as the "blue book," representing the agreed views of republicans who participated in the process. The model that emerged contained the following key elements. A community liaison team would be established, made up of trained volunteers with wide respect in the community. This team would receive and investigate complaints of "antisocial behavior" from the community, engage in informal mediation, issue informal cautions, or refer more complex cases to the mediation service, a group of trained voluntary mediators, to reach an agreed solution. As a last resort, contested cases would be referred to a community forum that has the "power" to impose an outcome. Typically these could include a mediated agreement, work with families, restitution, payment of damages, referral to a program or statutory agency, and community service. The ultimate sanction envisaged by the forum was a community boycott or "the right of the community to refuse to have persons living in its midst who consistently and seriously flout the norms of tolerable behavior as codified in a community charter" (Auld, Gormally, McEvoy, \& Ritchie, 1997, pp. 27-33).

In January 1999, CRJ, with the backing of Sinn Féin, launched five pilot projects in Derry and Belfast aimed at addressing "antisocial behavior." ${ }^{8}$ This has grown to more than 14 projects throughout Northern Ireland involving some 300 volunteers working in the scheme, and demand is still growing from communities for participation. Reports from project workers suggest that about two thirds of their workload is with older adults, and the remainder, largely young males under the age of 25, the target group for victims of "punishment" beatings (Interview with project workers, May 2000). Sinn Féin advice centers now refer dispute cases directly to CRJ who, in turn, collaborate with a range of statutory and voluntary organizations when they do not have the expertise to deal with particular 
cases/issues such as alcohol and drugs problems. Republican schemes have experienced problems in collaborating with statutory organizations. Senior managers "because of political interference from the Northern Ireland Office" officially object to working with CRJ, but middle management cooperate in a pragmatic way. It is, they argue, up to the statutory bodies, in particular the police, to come to terms with the fact that vibrant republican communities exist and they should be working with and developing new models of best practice through monitoring standards and ongoing support (Knox \& Monaghan, 2002).

In 2005, the Northern Ireland Office entered into a consultation period in relation to community-based restorative justice schemes and produced draft guidelines for such schemes (Northern Ireland Office, 2005). Following this, the Northern Ireland Office (2007) published a Protocol for Community-based Restorative Justice Schemes outlining a framework for relations between such schemes and the formal criminal justice system. Schemes are expected to operate in full accordance with the following: the Human Rights Act 1998, the United Nations Convention on the Rights of the Child, all current equality legislation in Northern Ireland, and the relevant sections of the UN's "Basic Principles on the use of Restorative Justice Programmes in Criminal Matters." Media reports had previously suggested that private financial assistance for community-based restorative justice projects was because of run out and that existing schemes would need to sign up to Government guidelines to secure funding (Thornton, 2006). Four loyalist restorative justice schemes including the Greater Shankill Alternatives have now secured government approval. To date, no republican scheme has been approved, although Jim Auld (2006), the Director of CRJ, wrote prior to Sinn Féin's public endorsement of the Police Service of Northern Ireland (PSNI) in January 2007, that although CRJ "supported these [draft guidelines] in principle ... We will not be able to formally implement agreed arrangements for processing criminal cases until there is an overall political settlement on policing" (p. 10).

\section{Community-based Restorative Justice in South Africa}

Informal justice has a long history in South Africa. Prior to colonization, the indigenous African population had developed its own set of laws, customs and institutions. These processes emphasized the reconciliation of disputing parties and the restoration of harmony within the community. If an offending party was found guilty, they were shamed and then reintegrated into the community. The reemergence of lekgotla-like practices during the apartheid years can be viewed as attempts to revive this restorative justice tradition and develop mechanisms that meet the needs of the people. With the ending of apartheid, one of the main priorities of the "new" legitimate and democratically elected government was to make justice accessible to all. This was to be achieved by transforming the formal criminal justice system. The Commission (1999) identified two challenges to this transformation process: (a) a justice system that is acceptable and accessible to all and (b) a system that incorporates the concept of restorative justice as one closer to indigenous approaches to dispute resolution. The Commission (1999) noted that,

The present system of justice is based predominately on one approach of resolving disputes, namely the adjudicative approach ... there is another approach where parties resolve their own disputes through a process of reconciling their different interests . . . It is about constructing 
resolutions to disputes which allow the interests of both parties to be met as opposed to deciding the dispute on the basis of one of the parties winning and the other losing. (p. 10)

The current debate is therefore focused on what type(s) of alternative community-based dispute resolution structures should be endorsed by the state and what sort of relationship should exist between the formal courts and these informal structures. This article considers two programs operating in the Western Cape that resemble the structures advocated by the Commission (1999) in their discussion paper "Community Dispute Resolution Structures"- the Community Peace Programme's (CPP) Peace Committees and the Guguletu Community Forum.

\section{The CPP's Peace Committees}

The CPP is a nongovernmental organization with a long history of involvement in dispute resolution. ${ }^{9}$ The CPP's model of community-based conflict resolution involves the establishment of a Peace Committee comprised of local people. Members may volunteer their services and can be elected or recommended by other community members. Half of the Peace Committee must be female with membership lasting for 6 months in the first instance and this is subject to renewal (CPP, n.d.). Peace Committee members are given training in facilitation and then offer their services to the local community. Referrals to the Peace Committee can come directly from an individual's party to a dispute, from police officers at the local station level (before charges are laid), and in some cases from assistant magistrates. No distinction is made between civil and criminal cases although in practice there are constraints as to the type of dispute or problem that Peace Committees can deal with. For example, cases involving murder fall outside the jurisdiction of the Committees. Furthermore, they are unable to deal with disputes that are already being dealt with by the police. Peace Committees thus deal with a range of cases involving assault, domestic violence, theft, trespass, and unpaid loans (Interview with John Cartwright, CPP, February 2001). They also deal with matters that do not fall into the normal ambit of justice or policing, for example, insults between neighbors. Such incidents in the townships have the potential to escalate from irritation to assault through to shack burning.

On receipt of a referral, Peace Committee members first approach the individuals involved in the dispute or problem to see if they are willing to attend a meeting. At the meeting, the Peace Committee tries to ascertain the facts of the case. Those directly involved in the dispute/problem are given the opportunity to tell their version of events, as are other community members who believe they have been affected by the dispute/problem. The facilitator encourages those present to think about a plan of action that will make things better thereby shifting the focus of attention from what happened in the past to what can be done in the future. Peace Committees do not take sides in disputes nor apportion blame. The case is concluded when those present agree on a resolution, which is monitored by a community member. Outcomes vary and may include the payment of expenses to the injured party/ies, the return of goods/moneys and/or an apology. According to the CPP (n.d.), more than $90 \%$ of Peace Committee meetings held in Zwelethemba (site of the pilot project established in 1997) reached a resolution. If, however, no agreement is made, then the matter may be taken to the police. At no point in the process is coercion exerted either physical or otherwise. The stated aim of Peace Committees is "to heal, not to hurt."

There are currently 20 Peace Committees in operation (February 2005), which have facilitated more than 11,000 peace-gatherings (Cartwright \& Jenneker, 2005). Research 
undertaken by Roche (2002) found that the Peace Committees were not only committed to a restorative process but also a restorative set of values. Roche concluded that,

Peace committees, however, at this stage appear to provide townships with a better experience of informal justice. Peace committees are not a vehicle for extending state control, or a forum for dealing with trivial grievances in a heavy-handed way. (p. 531)

The CPP is not the only restorative justice scheme in the townships of the Western Cape; an alternative scheme involving adjudication is also operating. This scheme will now be outlined.

\section{Guguletu Community Forum ${ }^{10}$}

The Guguletu Community Forum, previously known as the Guguletu Community Court, was officially launched on the May 17, 1998 and emerged from the hierarchical structure of community-based mechanisms of ordering and conflict resolution (i.e., street committees, area committees, etc.) that exist within the township. At the bottom of this hierarchy are the street committees; if a case cannot be dealt with here, then it is passed to the next level until it reaches the Forum that represents the whole community. The Forum has approximately 20 elected members. Forum sessions take place on a weekly basis, usually on a Sunday at a local community centre. These sessions are open to anyone who wishes to attend thereby ensuring transparency. Referrals can come from a variety of sources including self-referral from individuals who have a problem/dispute or from persons (complainants and defendants) who are in the process of going through the formal criminal justice system. Furthermore, Forum members may become aware of a dispute and offer their services to those involved. A number of cases come directly from the police either before a charge is laid or after a complaint is made. Senior prosecutors at the local magistrate's courts also refer cases and suspend the charge from the court roll until such time as the case is either resolved by the Forum or passed back to the prosecution services.

The Forum deals with a range of disputes including disagreements over money, house break-ins, domestic violence, malicious damage to property, assaults, theft and arguments concerned with the rightful ownership of property. The Forum does not, however, deal with cases of rape, murder, or armed robbery. On taking on a case, Forum members investigate the matter and call on all those involved in the dispute or problem to attend the Forum. Attendance is purely voluntary although no one to date has refused to attend. Parties to the dispute can call witnesses and present their version of events. The Forum aims to help those in conflict arrive at a remedy that restores the parties to a situation as close as possible to where they were before the conflict arose. This involves the victim or complainant in a process in which the offender takes responsibility for their actions and allows for the reparation of relations between the two. The Forum allows for mediation, offers solutions to correct an injustice and supervises the implementation of the decision. In most cases, a negotiated settlement is reached between the parties but the Forum is also able to adjudicate and pass judgment. Outcomes vary from an apology, the payment of compensation or expenses, the return of goods or moneys, and/or the undertaking of community service such as cleaning the community centre. 
In $80 \%$ of the 200 cases dealt with by the Forum in its first 10 months of operation, a resolution was found. The remaining $20 \%$ were either referred back to the formal criminal justice system or passed to other structures to deal with. For instance, according to Sipho Citabatwa, the Forum's Coordinator, a dispute between a church congregation and its minister was passed to the relevant church council (Interview, March 1999). The Forum's acceptability and authority is derived from the support it receives from the community.

There is much support for restorative justice from the South African government evidenced by commitments to the idea and practice in numerous policy documents including Law Commission projects, legislation, policy white papers and strategies (Batley, 2005). In 2005, the Department of Justice and Constitutional Development announced a 3-year project designed to establish a national restorative justice program. However, Skelton and Batley (2006) note that "the project has not yet been established, but indications are that this is likely to take place during 2006" (p. 23).

\section{Impact on Community-Based Retributive Justice Mechanisms?}

What impact, if any, has the emergence of restorative justice had on paramilitary assaults_- "punishment" beatings, and shootings in Northern Ireland and vigilante attacks in South Africa? Views range from "it is too early to assess" to "the experiment in restorative justice has been a significant success." McEvoy (2000, p. 4), for example, one of the coauthors of the "blue book," argues: "I think you have got to give the scheme time to work. It is very early days and there is no question that the CRJ schemes were designed to achieve long-term objectives." Jim Auld (Interview, May 2000), Project Director for Community Restorative Justice Ireland, claimed, "there is a direct correlation between the scheme and the decline in 'punishment' attacks." He subsequently argued that from their own research evidence "around $90 \%$ of victims and offenders were satisfied with the outcomes of the restorative process and some 80\% do not reoffend." Winston (Interview, May 2000), Project Manager in the Greater Shankill Alternatives program, reports similar successes: "Three years ago there were 15-20 'punishment' attacks each year, now you're lucky if there's one or two in this area. There might be more elsewhere but we can only deal with what we have here. So that's a vast improvement." The coordinator of the CPP scheme is naturally enthusiastic about the Peace Committees and explains that not only are community members becoming frustrated with vigilantism but that some vigilante groups have "realised that actually the time was past for acting beyond the law" (Interview, February 2001). Both the CPP and Guguletu Community Forum claim significant success rates in terms of resolving disputes or problems, $90 \%$ and $80 \%$, respectively.

Feedback from those involved in the schemes, however, illustrate the problems in measuring impact. While ultimately in terms of Northern Ireland, the projects aim to eradicate "punishment" attacks in South Africa, they seek to provide mechanisms by which community members can resolve their disputes; however, there are intermediate goals that need to be achieved before this can happen. They must, for example, engage in an awareness and education program to inform communities what their role is and to convince them of the merits of restorative justice as a mechanism to deal with community crime, disputes, and problems. This, in itself, is a major task. There is clearly suspicion about the motives of those involved and a 
Figure 2

Recorded "Punishment" Shootings 1973-2006

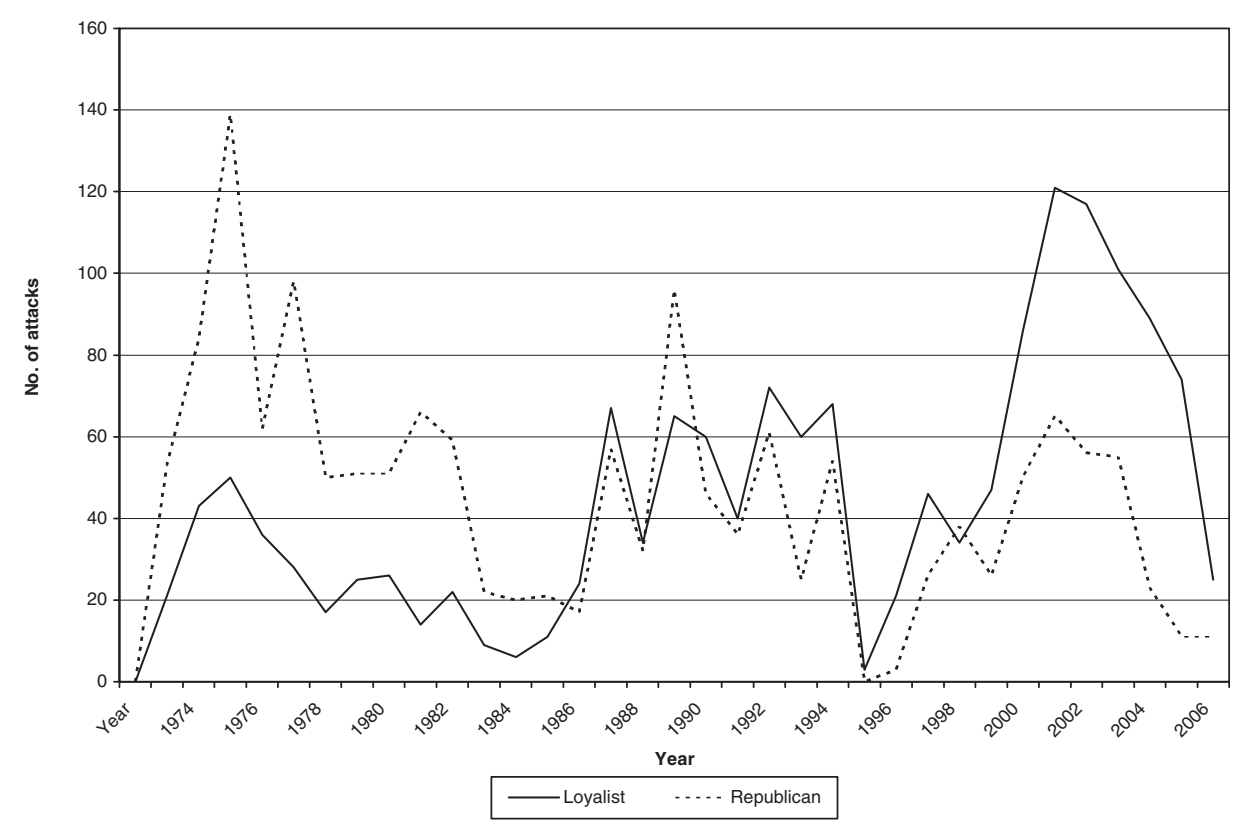

Source: Police Service of Northern Ireland.

natural misgiving that restorative justice represents a soft option. In the case of the former, communities see "ex-combatants" or former vigilantes now centrally involved in restorative justice programs and question the veracity of their claims to act impartially on their behalf ${ }^{11}$ the "poacher turned gamekeeper" accusation. In terms of the latter, communities that have demanded and witnessed "rough justice" through physical violence against perpetrators of petty crime are unlikely to immediately embrace apologies, reparation, and community service as an effective alternative. Other intermediate objectives could, for example, consider the number and nature of referrals to the schemes. In terms of Northern Ireland, if political parties and paramilitary groups increasingly refer complainants to restorative justice projects, their endorsement can be taken as a measure of its effectiveness in dealing with problems they would otherwise become involved with. Similarly, unsolicited approaches to restorative schemes are not only a measure of community awareness but, if effective, an indicator of community confidence in nonviolent alternatives. Is the impact of these schemes borne out by the data?

Looking at the police statistics for recorded beatings and shootings (see Figures 2 and 3), several points can be made. ${ }^{12}$ The cease-fires of August (republican) and October (loyalist) of 1994 witnessed a significant decrease in the number of shootings to the lowest recorded level, a total of three in 1995; however beatings increased by more than $300 \%$ in the previous year (Figure 3). 
Figure 3

Recorded "Punishment" Beatings 1982-2006

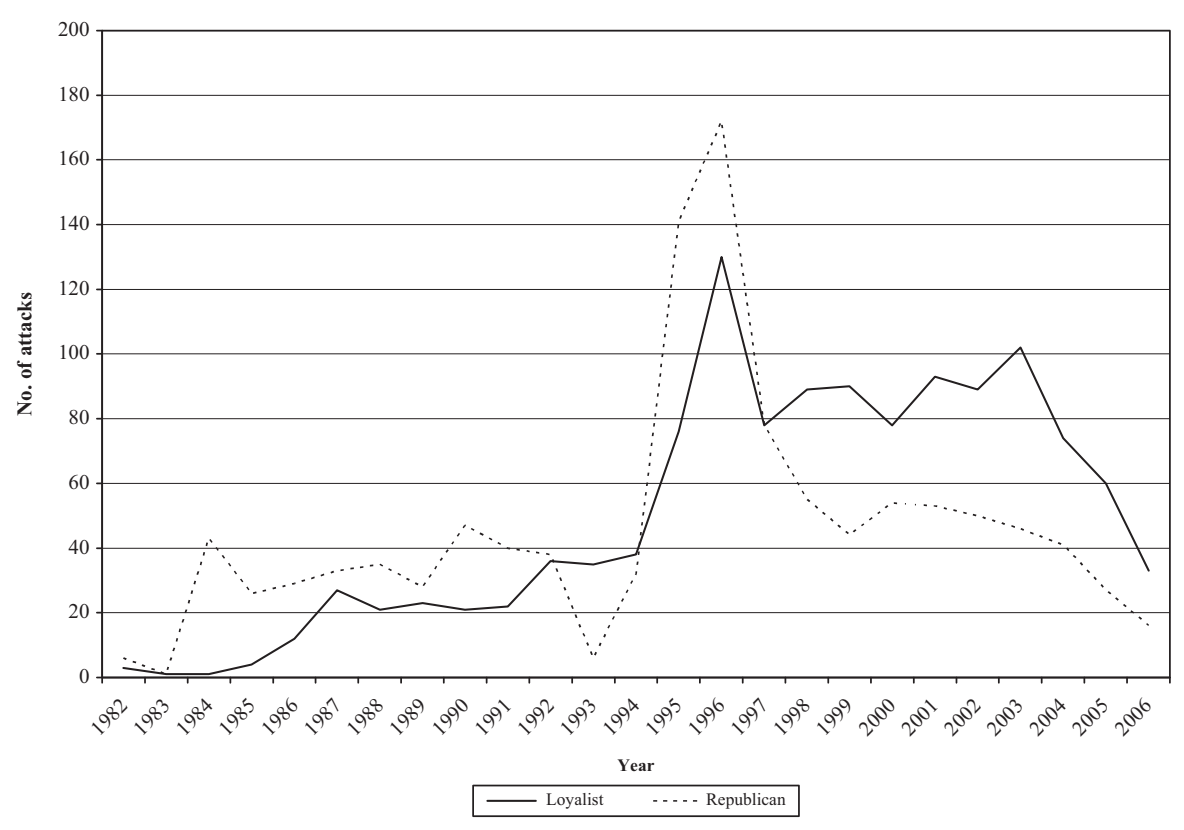

Source: Police Service of Northern Ireland.

An increase in shootings can be observed from 1996 onwards and in 2000; recorded numbers of "punishment" shootings (136) exceeded the number of beatings (132). This increase can in part be explained by the failure of Northern Ireland Secretaries of State to rule that "punishment" shootings and indeed beatings constitute a breach of the cease-fires. Interestingly, in the year following the signing of the Belfast Agreement up until the end of 2005, the number of loyalist "punishment" attacks has been greater than the number of republican attacks in each year. Loyalist paramilitaries have accounted for $65 \%$ of "punishment" beatings and $69 \%$ of shootings between 1999 and 2005. Since 2003, a reduction in the number of "punishments" can be observed, and in 2005 the total number was at its lowest since 1994 (statistics available on the PSNI's Web site). The International Monitoring Commission (2006, p. 19) noted that since the PIRA's statement of July 28, 2005, it has ceased sanctioned "punishment" attacks although it was aware of at least six unreported assaults mostly resulting from "personal disputes ... [that] have been without leadership authority or planning, though in the process can carry with them the aura of PIRA threat."

Considering the intervention of the restorative justice program from January 1999 onwards, loyalist shootings increased to their highest recorded level in 2001 and beatings remained roughly the same. Republican shootings and beatings dropped in 1999 but subsequently increased until 2001-they have been declining since then. Looking crudely at the figures, therefore, would suggest that restorative justice schemes have had little or no 
impact on the overall trend in "punishment" attacks. This is particularly true of the loyalist community where shootings and beatings exceeded those in republican areas. The trends outlined can be observed in Figures 2 and 3.

There are clearly deficiencies in assessing impact through these statistics, not least because of the inability to isolate cause and effect variables in the restorative justice schemes and establish the counterfactual position-in the absence of the program the beatings and shootings could have been much higher. Indeed, McEvoy and Mika (2002) note "that assessing their impact statistically is complex" (p. 541), because of police statistics being attributed solely to loyalists and republicans and not to individual paramilitary groups and that the figures are for the whole of Northern Ireland and are not available on a localized basis. A time-series analysis was undertaken, but no significance was found in terms of key dates such as the introduction of the restorative justice schemes. The level of "punishment" attacks may have little to do with what happens within these programs but be subject to extraneous factors over which they have no control. The loyalist turf feud between factional groups in the Shankill in 2000, for example, probably resulted in a number of "housekeeping" attacks by paramilitaries. In terms of South Africa, no statistics are kept by the South African Police Service on assaults or shootings perpetrated by vigilantes. Therefore, it is very difficult to ascertain whether the introduction of restorative justice schemes has had any effect on levels of vigilantism. Developments in the wider political landscape such as police reforms and changes in the criminal justice system will affect the continuance or otherwise of "punishment"/vigilante attacks. Furthermore, Dixon (2004, p. 374) draws our attention to the point that in terms of the CPP there is very little "independent evaluative data to go on." Indeed, what has been published has been authored either by Shearing (who as already noted was involved in the Community Peace Foundation) or by researchers utilizing data provided by the CPP (Roche, 2002). The information about the workings of the South African schemes was based on qualitative data gained through semistructured interviews with representatives of those schemes.

Proponents of restorative justice both in Northern Ireland and South Africa argue that it must be seen as a long-term project addressing the root causes of "antisocial behavior" or community problems rather than its symptoms (McEvoy \& Mika, 2002; Nina, 1995).

\section{Conclusions}

The description of restorative justice schemes in Northern Ireland (the Greater Shankill Alternatives program and CRJ) and South Africa (Guguletu Community Forum and the CPP's Peace Committees) serves to illustrate their very different historical antecedents and operational detail. Each of the four schemes discussed was found to have a tripartite relationship between victims, offender, and the community. This relationship sought to (a) meet the needs of victims, (b) make the offender accountable for their actions, and (c) give the communities involved a sense of ownership and responsibility in terms of dealing with crime. The question posed as to whether such schemes have affected the violent system of punitive sanctions perpetrated by paramilitaries in Northern Ireland or vigilantes in South Africa remains difficult to answer definitively. The absence of crime statistics in the latter, and capacity to screen out extraneous variables which may affect crime in the former, means that qualitative responses have been relied on from those involved. Often, views expressed are tendentious 
because of the vested interests of the stakeholders involved such as police and communitarians. Both countries seem receptive to the integration of restorative justice programs within their formal justice systems but this must involve recognition of, and collaboration with, the organs of the state. For ideological reasons, and/or lack of confidence in the effectiveness of the state's formal justice system, this may not be possible for some communities currently supportive of grassroots restorative justice initiatives. Moreover, to expect restorative justice programs to deal with crime (often violent) which has been the preserve of paramilitaries or vigilantes is to demand too much of them. This dumbing down of expectations has been realized in South Africa but not yet in Northern Ireland, where the introduction of restorative justice programs is hailed as the panacea for "punishment" beatings by paramilitaries. The South African experience would suggest that there is an important role for restorative justice schemes but one which runs in parallel with, rather than substitutes for, the formal (or indeed informal) retributive system. Vigilantism continues in South Africa and paramilitary involvement in community crime persists in Northern Ireland.

The lessons of South Africa for Northern Ireland are clear. Restorative justice schemes do offer an effective mechanism for resolution of disputes and petty crime, but they cannot survive as alternative justice systems that attempt to work outside the rubric of the state under the auspices of paramilitaries who see themselves as administering the ultimate sanction for the less compliant. In Northern Ireland and South Africa, there is still strong support for summary justice, a legacy of years of violent struggle. There are several similarities in both countries' transition to a postconflict scenario. Constitutional settlements have been no guarantee of a reduction in "normal" crime, and the statistics would suggest an inverse relationship. There is an obvious time lag in moving from transitional status where the formal justice system remains ineffectual and politically tainted to one that can command the credibility and trust of the community/ies. The nature of the conflict has caused those most affected to look inward for protection, not outward to the state. With the move to new political dispensations, there have been attempts at "regulatory capture" of community-based restorative justice schemes by the state, ostensibly in the interests of human rights protection and securing due process for those accused. This has resulted in a hiatus. The transition to acceptable and effective policing and criminal justice systems inevitably is taking longer than envisaged, which provides justification for paramilitaries and vigilantes to tackle violent crime. Meanwhile restorative justice schemes operating outside the state system are criticized as "alternative" justice systems. Those integral to the formal system are increasingly regulated to the extent that they are seen by communities as little more than minor dispute centers with limited clout and even less jurisdiction in the area of violent crime. It should be borne in mind that the legitimacy of local restorative justice programs comes from the community which must recognize their value and support their modus operandi. If this community ownership is wrested from them, and they become part of the formal justice system, then they may not be seen in the same light.

South Africa also provides some insights into the future direction of informal "justice" in Northern Ireland. The "comrades" in South Africa, postsettlement, no longer wanted to be involved in vigilante-type activity aimed at tackling community crime. They have been displaced by professionalized mobs such as PEACA and Mapogo running crime prevention operations. The paramilitaries in Northern Ireland now publicly eschew involvement in community crime. In practice, however, "punishment" gangs are likely to have direct links with paramilitaries. Racketeering and "protection" money is part of their core funding. Similarly in Northern 
Ireland a two-tier system is developing. Community restorative projects deal with minor disputes and petty crime but more serious issues are dealt with by paramilitaries and the inexorable lust for summary "justice" has resulted in more brutal consequences (necklacing and six packs). While the formal policing and justice systems in both countries struggle to achieve legitimacy and effectiveness, restorative justice schemes are perceived as "first-aid clinics" for minor disputes and petty crime. Beyond that, there remains the hard men of violence still wedded to punitive measures and seemingly untouched by attempts to reform the formal system.

\section{Notes}

1. The Assembly was suspended again (for the fourth time) in October 2002 following the discovery of an "alleged" Provisional Irish Republican Army (PIRA) spy ring. Charges against Sinn Féin's Denis Donaldson were later dropped; he was revealed as an informer and subsequently found murdered in a remote area of Donegal in April 2006. Devolution was restored in Northern Ireland on the May 8, 2007.

2. Figures for shootings and beatings were first recorded in 1973 and 1982 respectively, and show that loyalists were responsible for $50 \%$ of the shootings and $52 \%$ of the beatings; republicans carried out the remainder.

3. PEACA is based in Khayelitsha, a township near Cape Town. It was formed in August 1998 by excombatants of the liberation struggle, who came together to fight crime. Its members number 1,500.

4. Mapogo a Mathamaga was established in August 1996 and has some 50,000 members who pay a monthly subscription to the organization in return for protection against crime.

5. The Royal Ulster Constabulary adopted a number of the recommendations made by the Patten Report (named after the Independent Commission on Policing for Northern Ireland's chair) including a name change to the Police Service of Northern Ireland and a 50:50 recruitment policy of Catholic: Protestant recruits (Report of the Independent Commission on Policing for Northern Ireland, 1999).

6. NIACRO is a major charity working with prisoners, their families, ex-offenders, and young people at risk of offending. It also works "for a more humane and effective criminal justice system." The position of NIACRO is an interesting one, in that most of its core funding comes via the Northern Ireland Office, which was very sensitive about any direct linkage with this work, lest it be construed as encouraging or endorsing parallel justice systems.

7. The UVF is a loyalist paramilitary group (formed in 1966) responsible for a large number of assassinations, mostly innocent Catholics, in Northern Ireland. In 1996, a number of disaffected "maverick" members broke away to form the Loyalist Volunteer Force (LVF). The UDA formed in 1971 from a number of loyalist vigilante groups, many of which were called "defense associations"-was, and remains, the largest loyalist paramilitary group. Members of the UDA have, since 1973, used the cover name of the Ulster Freedom Fighters (UFF) to claim responsibility for the killing of Catholics. The Ulster Democratic Party which earned a place at the multiparty talks following the Forum elections in May 1996 represented the UDA until it folded in November 2001. The Red Hand Commando is a small loyalist paramilitary group closely associated with the UVF. They formed in 1972 and have most support in east Belfast and the Sandy Row area. The group was declared illegal in 1973.

8. Pilot projects were launched in Derry (Ballymagroarty) and north and west Belfast (Clonard, Beechmount, the New Lodge, and Twinbrook).

9. The CPP is the successor organization to the Community Peace Foundation (CPF). The CPF was established by Clifford Shearing (a South African born Canada-based academic) at the bequest of the ANC in the early 1990s and was primarily a policy think tank concerned with issues of crime and policing. It also offered practical training in "community policing." For example, at the time of the first elections in 1994, it trained local people as election marshals.

10. The following information is based on interviews with Community Forum members undertaken by the author. Guguletu is a Black township located on the outskirts of Cape Town in the Western Cape with an estimated population of more than 150,000.

11. Tom Winston (Alternatives) received a life prison sentence for his part in a UVF squad which murdered two Catholics in West Belfast. Harry Maguire (CRJ, Andersonstown) served 10 years for the murders of two army corporals and was released under the terms of the Belfast Agreement. Paddy O'Carroll (CRJ, Derry) was 
jailed for 18 years in 1979 for weapons and explosives offences and served 10 years. In South Africa, Sipho Citabatwa (Guguletu Community Forum) had been involved in the sjambokking of criminal elements within the township. Vigilante-type groups such as the Disciplinary Committee in Beaufort West have approached the CPP about establishing Peace Committees in their areas.

12. It should be borne in mind that these statistics are thought to underrepresent by as much as $30 \%$ to $50 \%$ the extent of paramilitary attacks, many of which go unreported for fear of reprisal among victims. Police statistics for paramilitary assaults and shootings are publicly available on the Police Service of Northern Ireland's Web site at the following address http://www.psni.police.uk/index/statistics_branch/pg_security_stats.htm

\section{References}

Altbeker, A. (2005). Positive trends: The 2004/05 crime statistics. South Africa Crime Quarterly, 14, 1-10.

Auld, J. (2006, March 26). Why the SDLP has it wrong. Sunday World, p. 10.

Auld, J., Gormally, B., McEvoy, K., \& Ritchie, M. (1997). Designing a system of restorative community justice in Northern Ireland: A discussion document. Belfast, UK: Authors.

Barclay, G. C., \& Tavares, C. (2000). International comparisons of criminal justice statistics. London: Home Office.

Batley, M. (2005). Outline of relevant policies. In T. Maepa (Ed.), Beyond retribution: Prospects for restorative justice in South Africa (pp. 120-126). Pretoria, South Africa: Institute for Security Studies and the Restorative Justice Centre.

Bell, C. (1996). Alternative justice in Ireland. In N. Dawson, D. Greer, \& P. Ingram (Eds.), One hundred and fifty years of Irish law (pp. 145-167). Belfast, UK: SLS Legal.

Boehrer, F. (2006). The Good Samaritan or the person in the ditch? An attempt to live a restorative lifestyle. In D. Sullivan \& L. Tifft (Eds.), Handbook of restorative justice (pp. 546-554). London: Routledge.

Braithwaite, J. (2003). Principles of restorative justice. In A. von Hirsch, J. V. Roberts, A. Bottoms, K. Roach, \& M. Schiff (Eds.), Restorative justice and criminal justice (pp. 1-20). Oxford, UK: Hart.

Braithwaite, J., \& Strang, H. (2001). Restorative justice and civil society. In H. Strang \& J. Braithwaite (Eds.), Restorative justice and civil society (pp. 1-13). Cambridge, MA: Cambridge University Press.

Brewer, J. D., Lockhart, B., \& Rogers, P. (1998). Informal social control and crime management in Belfast. British Journal of Sociology, 49, 570-583.

Brogden, M., \& Shearing, C. (1993). Policing for a new South Africa. London: Routledge.

Burton, P., du Plessis, A., Leggett, T., Louw, A., Mistry, D., \& van Vuuren, H. (2004). National victims of crime survey: South Africa 2003 (ISS Monograph Series No. 101). Pretoria, South Africa: Institute for Security Studies.

Cartwright, J., \& Jenneker, M. (2005). Governing security: A working model in South Africa-The peace committee (Criminal Justice Conference February 7-8). Retrieved July 4, 2006, from http://www.csvr.org.za/confpaps/ cartwright.htm

Community Peace Programme. (n.d.). Community peace-making: Building a model of democratic governance. Cape Town, South Africa: Author.

Consedine, J. (1999). Restorative justice: Healing the effects of crime. Lyttelton, New Zealand: Ploughshares.

Conway, P. (1997). A response to paramilitary policing in Northern Ireland. Critical Criminology, 8, 109-122.

Dignan, J., \& Lowey, K. (2000). Restorative justice options for Northern Ireland: A comparative review. Belfast, UK: Stationery Office.

Dixon, B. (2004). In search of interactive globalisation: Critical criminology in South Africa's transition. Crime, Law and Social Change, 41, 359-384.

Doyle, S. (2001, April 30). Ex-drug dealer shot six times. Irish News (Belfast), p. 11.

The Economist. (2003, October 11). Small mercies: Crime in South Africa. The Economist, p. 66.

Gil, D. G. (2006). Toward a "radical" paradigm of restorative justice. In D. Sullivan \& L. Tifft (Eds.), Handbook of restorative justice (pp. 499-511). London: Routledge.

Gilbert, M. J., \& Settles, T. L. (2007). The next step: Indigenous development of neighbourhood-restorative community justice. Criminal Justice Review, 32, 5-25.

Hall, M. (2000). Restoring relationships: A community exploration of anti-social behaviour, punishment beatings and restorative justice. Newtownabbey, UK: Farest Community Think Tank Project. 
Hillyard, P. (1985). Popular justice in Northern Ireland: Continuities and change. Research in Law, Deviance and Social Control, 7, 247-267.

Hosken, G. (2006, June 23). Alleged robbers stoned by angry villagers. The Pretoria News, p. 2.

Independent International Commission on Decommissioning. (2005, September 26). Report of the independent international commission on decommissioning. Belfast, UK: Author.

International Monitoring Commission. (2006). Eighth report of the independent monitoring commission. London: The Stationery Office.

Kennedy, L. (1995). Nightmares within nightmares: Paramilitary repression within working-class communities. In L. Kennedy (Ed.), Crime and punishment in West Belfast (pp. 67-80). Belfast, UK: The Summer School, West Belfast.

Knox, C., \& Monaghan, R. (2002). Informal justice in divided societies. Basingstoke, UK: Palgrave Macmillan.

Marshall, T. F. (2003). Restorative justice: An overview. In G. Johnstone (Ed.), A restorative justice reader (pp. 28-45). Cullompton, UK: Willan.

Mbeki, T. (1999). Presidential inauguration speech. Retrieved July 4, 2006, from http://www.anc.org.za/ ancdocs/history/mbeki/1999/tm0616.html

McEvoy, K. (1999). Introduction to Restorative Justice. In NIACRO (Ed.), Reflections on restorative justice in the community (pp. 17-20). Belfast, UK: NIACRO.

McEvoy, K. (2000, October 7). Working to end the back-alley "justice". The Irish News, p. 4.

McEvoy, K., \& Mika, H. (2002). Restorative justice and the critique of informalism in Northern Ireland. British Journal of Criminology, 42, 534-562.

McGloin, J. M. (2006). A historical consideration of the police and prosecution/courts in Northern Ireland. International Criminal Justice Review, 16, 77-98.

McGuigan, C. (1999, March 22). Boy (13) is ordered out of country after beating. The Belfast Telegraph, p. 4.

Minnaar, A. (1995). Desperate justice. Crime and conflict, 2, 9-12.

Mistry, D. (2004). Falling crime, rising fear: 2003 National Victims of Crime survey. South Africa Crime Quarterly, 8, 17-24.

Monaghan, R. (2002). The return of "Captain Moonlight": Informal justice in Northern Ireland. Studies in Conflict and Terrorism, 25(1), 41-56.

Morrissey, M., \& Pease, K. (1982). The Black criminal justice system in West Belfast. Howard Journal, 21, 159-166.

Mowlam, M. (1999, August 27). Secretary of State's judgement on alleged breech of cease-fire. Belfast, UK: Northern Ireland Office.

Munck, R. (1984). Repression, insurgency, and popular justice: The Irish case. Crime and Social Justice, 21, 81-94.

Nina, D. (1995). Re-thinking popular justice. Cape Town, South Africa: Community Peace Foundation.

Northern Ireland Affairs Committee. (2001). Relocation following paramilitary intimidation. London: House of Commons.

Northern Ireland Office. (2005). Consultation on draft guidelines for community-based restorative justice schemes. Belfast, UK: Author.

Northern Ireland Office. (2007). Protocol for community-based restorative justice schemes. Belfast, UK: Author.

The Pretoria News. (2006, July 3). Man dies as dispute ends in mob justice. The Pretoria News, p. 3.

Report of the Chief Constable. (2000). RUC: 1999/2000. Belfast, UK: Royal Ulster Constabulary.

Report of the Chief Constable. (2007). Police service of Northern Ireland: 2006-2007. Belfast, UK: PSNI.

Report of the Independent Commission on Policing for Northern Ireland. (1999). A new beginning: Policing in Northern Ireland. Belfast, UK: HMSO.

Roche, D. (2002). Restorative justice and the regulatory state in South African townships. British Journal of Criminology, 42, 514-533.

Seekings, J. (1992). The revival of "People's Courts." In G. Moss \& I. Obery (Eds.), From "Red Friday" to Codesa (pp. 186-200). Johannesburg, South Africa: Raven Press.

Silke, A. (1999). Ragged justice: Loyalist vigilantism in Northern Ireland. Terrorism and Political Violence, 11, 1-31.

Skelton, A., \& Batley, M. (2006). Charting progress, mapping the future: Restorative justice in South Africa. Pretoria, South Africa: Institute for Security Studies. 
Soggot, M., \& Ngobeni, E. (1999, May 14). We must work on their buttocks. Weekly Mail and Guardian (Johannesburg). Retrieved May 30, 2000, from http://www.mg.co.za/articledirect.aspx?articleid=161459\& area $=\% 2$ farchives $\% 2$ farchives_print_edition $\% 2 \mathrm{f}$

South African Institute of Race Relations. (2001). South Africa Survey 1999/2000. Johannesburg, South Africa: Author.

South African Law Commission. (1999, October). Community dispute resolution structures. Discussion Paper 87, Project 94.

South African Law Commission. (2003). Conviction rates and other outcomes of crimes reported in eight South African police areas. Research Paper 18, Project 82 (Sentencing).

South African Press Association. (2006, April 27). Angry mob kill suspected robber in Joburg. Independent on line. Available from www.iol.co.za

Sullivan, D., \& Tifft, L. (2000). Restorative justice as a transformative process. Voorheesville, NY: Mutual Aid Press.

Templeton, D. (2000, November 8). Mum's gun horror at hands of gang. The Belfast Telegraph, p. 3.

Thornton, C. (2006, January 26). CRJ cash conditions "must be tightened." The Belfast Telegraph, p. 2.

Winston, T. (1997). Alternatives to "Punishment" beatings and shootings in a loyalist community in Belfast. Critical Criminology, 8, 122-128.

Zehr, H. (2003). Retributive justice, restorative justice. In G. Johnstone (Ed.), A restorative justice reader (pp. 69-82). Cullompton, UK: Willan.

Rachel Monaghan is a lecturer in criminology at the University of Ulster (Northern Ireland). She has been researching informal justice in Northern Ireland for the past 8 years and has published extensively on this topic. Her $\mathrm{PhD}$ is from the University of Reading (England). She has examined the use of political violence by single-issue groups. 